\title{
IMPROVEMENT OF BUSINESS PROCESS FOR SME ON THE BASIS OF QUALITY SYSTEM
}

\author{
KARAUlOVA, T. \& OTTO, T.
}

Abstract: This paper addresses a need for modelling methods to support enterprise engineering. The enterprise engineering is a considered and systematic analysis and design of an enterprise through the business processes, which it employs to realize its business goals. The enterprise model contains the representations of individual facts, objects, and relationships that occur within the enterprise. BPM is a convergence of a number of existing technologies and approaches. Its primary roots are in the process management capabilities of workflow tools but it also includes the capabilities that derive from document management, process modelling, analytics, rules management, collaboration applications and application integration.

Key words: process model; systems management, ISO, modelling, business process
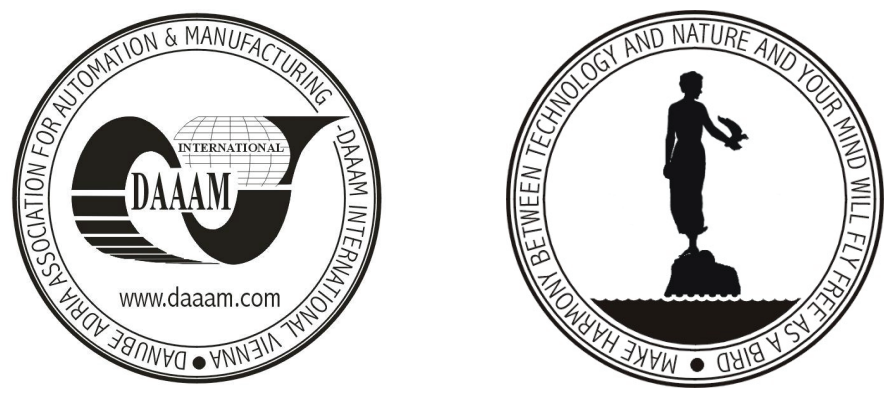

Authors' data: Ph.D. Karaulova T.[atyana], Ph.D. Otto T.[auno], Tallinn University of Technology, Estonia, tatjana.karaulova@ttu.ee, tauno@staff.ttu.ee

This Publication has to be referred as: Karaulova, T. \& Otto, T. (2006). Improvement of Business Process for SME on the Basis of Quality System, Chapter 26 in DAAAM International Scientific Book 2006, B. Katalinic (Ed.), Published by DAAAM International, ISBN 3-901509-47-X, ISSN 1726-9687, Vienna, Austria DOI: $10.2507 /$ daaam.scibook.2006.26 